\title{
O TEMPO E A ETERNIDADE
}

Edvino A. Rabuske*

SÍNTESE - As aporias do tempo cosmológico e do tempo psicológico são parcialmente superadas pela introdução do tempo histórico. A partir deste terceiro tempo é possivel recolocar um antigo problema, 0 da relação entre tempo e eternidade, explorado pelos mitos, pelas grandes religiões e pela Filosofia. A solução filosófica aqui proposta consiste em repensar, no nivel espiritual, o esquema aristotélico de ato e potência.

\begin{abstract}
The aporiae of the cosmological and psychological time are parcially surpassed, if there is introduced the historical time. Starting from this third time, it's possible to bring into focus an ancient problem, namely the relation between time and eternity, a subject explored by the myths, the great religions and Philosophy. The philosophical solution here proposed consists in reconsidering Aristotle's scheme of hylomorphism, on a spiritual level.
\end{abstract}

Nas ciências particulares pode ser válido que só conhecemos o que está no tempo e no espaço; acerca da eternidade nada sabemos. Mas na Filosofia não posso falar do tempo, sem me referir pelo menos indiretamente ao eterno. Não só a eternidade é um problema, também o tempo o é. Conhecida é a confissão de $\mathrm{S}$. Agostinho: "Se não me perguntam, sei o que é o tempo; se me perguntam, não sei mais". Em outros termos, tenho uma noção vaga do tempo, mas não a sei explicitar.

As considerações aqui apresentadas são, em grande parte, colhidas da obra de Paulo Ricoeur, Temps et récit, principalmente do terceiro volume, de 1985. É uma obra de difícil leitura por causa do grande número de autores e temas analisados. A originalidade do autor consiste na teoria dum terceiro tempo, "sintetizando" o tempo da alma e o tempo do mundo; é o tempo humano, histórico, configurado pela narração. Este tempo humano possibilita reavivar as idéias tradicionais sobre a eternidade.

Vou dividir estas considerações em três partes: I - a aporética do tempo; II uma solução parcial: a poética da narração; III - a eternidade, o outro do tempo. São considerações introdutórias, no duplo sentido da palavra: pretendem realmente introduzir a uma discussão racional do assunto, mas não pretendem chegar a soluções argumentativamente satisfatórias. Em Filosofia, a própria tomada de consciência dos problemas é importante, pois evita a superficialidade e as soluções ingênuas ou prematuras.

- Professor do Instituto de Filosofia e Ciências Humanas da PUCRS.

\begin{tabular}{|l|l|l|l|l|l|}
\hline VERITAS & Porto Alegre & v. 41 & $\mathrm{n}^{2} 161$ & Março 1996 & p. 5-26 \\
\hline
\end{tabular}




\section{I - A aporética do tempo}

\section{1 - Aristóteles}

O texto básico é o livro IV da Física. A tese central é a prioridade do movimento sobre o tempo. O tempo é "qualquer coisa do movimento" (Física IV, 11, 2, 9 a 10). $O$ argumento se desenvolve em três etapas:

a) O tempo não é um "princípio" da natureza (physis). O movimento está nas coisas mutantes, ao passo que o tempo está em toda parte e igualmente. Não há percepção do tempo sem percepção do movimento. "Que o tempo, portanto, não é nem movimento, nem sem movimento, eis o que está claro" (219 a 2).

b) A relação entre o antes e o depois, a partir da analogia entre três "entidades" contínuas: a grandeza (quantidade), o movimento e o tempo. Continuidade é a possibilidade de dividir ao infinito uma grandeza. A sucessão - antes e depois não é a primeira relação; procede por analogia duma relação de ordem que está no mundo antes que na alma. Esta é afetada, antes de construir.

c) Introdução do número, parà completar a definição: o tempo é o "número do movimento segundo o antes e o depois" ( $219 \mathrm{~b} 2$ ). A alma distingue dois instantes e um intervalo entre eles que pode ser numerado, contado, medido. Mas na base do número numerado está o número numerável. O número ou medida do tempo supõe a existência dum movimento regular, que é o das estrelas.

Aqui surge a pergunta embaraçosa: se "sem alma haveria ou não tempo" (223 a 21-22). Em resposta, Aristóteles recusa incluir na definição do tempo qualquer determinação psíquica. O tempo depende do movimento, que se enraíza na physis. $\mathrm{O}$ instante é o corte operado pela alma na continuidade do movimento enquanto numerável. $\mathrm{O}$ instante é o fim do antes e o começo do depois. O intervalo entre dois instantes é o que é mensurável. "O tempo é contínuo graças ao instante e dividido segundo o instante" (220 a 4). O instante é corte e laço, distingue e une. Só em potência o instante divide - tratamos o tempo como uma linha em repouso. A potência unificadora do instante repousa sobre a unidade dinâmica do móvel que, mesmo passando por muitos pontos fixos, continua o mesmo.

Esta concepção do tempo é difícil de compreender. A raiz da dificuldade está na compreensão do movimento como "ato da potência enquanto potência" (20 a 1011). Talvez o tempo cósmico se torne um pouco mais compreensível quando confrontado com o tempo psíquico, de S. Agostinho.

Se o tempo depende do movimento que se enraiza na physis, o tempo tem uma dimensão sobre-humana. Aqui Aristóteles deixa penetrar nas suas análises abstratas algo duma longa tradição: que o tempo nos cerca e nos domina. "Estar envolvido pelo tempo" parece dar ao tempo uma existência independente e superior às coisas. "As coisas sofrem de alguma maneira a ação do tempo" (221 a 30). A sabedoria imemorial do mito percebia uma secreta ligação entre a mudança que desfaz (esquecimento, envelhecimento, morte) e o tempo que simplesmente passa.

Ainda outra é a concepção do tempo apresentada na Ética e na Poética: o prazer, a sensação, a vida feliz se produzem dum só golpe. Entre não-ver e ver não há graduação, há um salto. O que acompanha o desenvolvimento do enredo duma tragédia não é o tempo duma gênese, com fases separadas entre si, mas o tempo 
duma ação dramática considerada como um todo. Só compreendo uma cena da tragédia se tenho presente a sua totalidade. Sobre isto voltaremos, quando tratarmos da passagem do tempo à eternidade.

\section{$2-S$. Agostinho}

S. Agostinho, no célebre livro XI das Confissões, apresenta a sua concepção psíquica do tempo. $O$ tempo da alma (animus, que também pode ser traduzido por "espirito") deriva da distentio da alma. O tempo não é simplesmente uma sucessão de instantes, mas tem uma continuidade, um estiramento, uma extensão. Esta extensão se explica porque o próprio espírito se distende, se "espicha", se estira. A referência ao movimento das coisas externas não tem papel constitutivo, só subsidiário. É a espera e a recordação que são o princípio da medida. A espera se encurta, quando as coisas esperadas se aproximam. Quando recito um poema, o passado cresce na medida em que o futuro diminui. Mas surge a pergunta: qual é a unidade fixa que permite comparar duas durações? Aristóteles buscou a unidade de medida no movimento regular dos astros, a partir do qual temos as unidades fixas do ano, do mês, do dia e suas divisões (hora, minuto, segundo).

A diferença decisiva entre Aristóteles e S. Agostinho é que o primeiro coloca no centro da sua concepção do tempo o instante; o segundo, o presente. $O$ instante é o corte operado pelo espírito na continuidade do movimento enquanto numerável. O instante é sempre um instante qualquer. Então há instantes que precederam e instantes que vão suceder, um antes e um depois. Supõe-se um espírito que sobrevoa o mundo das mudanças. Pelo contrário, o presente é o "agora" da enunciação, o momento em que um locutor se refere a si mesmo; o presente é reflexivo, sui-referencial. Por exemplo, a promessa (ato de fala comissivo) é um ato realizado no presente, em que um sujeito se obriga a cumprir uma ação no futuro. Ao presente corresponde o passado e o futuro; 0 antes e o depois de Aristóteles só correspondem ao instante qualquer. Claro que posso me referir a um "presente" que hoje é passado. P. ex., Cristo disse: "Vou a Jerusalém". Este presente, que para mim é um quase-presente, tinha o seu futuro, que para mim é o futuro do passado: "Foi a Jerusalém para realizar a sua missão de morrer e ressuscitar".

Uma última diferença. Segundo Aristóteles, o instante divide e une. A potência unificadora do instante repousa sobre a unidade dinâmica do ser móvel, que mesmo mudando continua sendo o mesmo. S. Agostinho fala dum tríplice presente: 0 presente do passado, o presente do futuro e o presente do presente. 0 passado, embora abolido na sua facticidade, continua no seu sentido na memória, influenciando o presente. O futuro, embora ainda não seja facticamente, está antecipado na expectativa do sujeito que age, orientando a sua ação. O presente é o "agora" que recolhendo o futuro e o passado, intervém no curso das coisas. Retentio, protentio e attentio constituem a tríplice estrutura do presente.

Ainda ficam muitas dúvidas. Afinal, é o tempo que passa ou somos nós que passamos "no tempo". Antecipando uma temática de que ainda vamos tratar, o que significa dans le temps, com que Marcel Proust termina seu romance La recherche du temps perdu? Onde esse autor acha reencontrar o tempo perdido? Em que sen- 
tido este lugar é a obra de arte? Também o interesse fundamental de $\mathrm{S}$. Agostinho é confrontar o tempo que passa com a eternidade do nunc stans (agora parado?).

\section{3-Kant}

Kant afirma o caráter indireto do tempo. O tempo não aparece, mas é uma condição de todo aparecer. $\mathrm{O}$ autor faz uma dupla abstração: a sensibilidade é isolada do pensamento; a forma é separada do diverso (matéria). A justificação deve ser fornecida pela Crítica da razão pura inteira.

$\mathrm{Na}$ Estética transcendental Kant pergunta inicialmente "o que são o espaço e o tempo?" Das quatro respostas: são substâncias, são acidentes, são relações reais, são relações que surgem da constituição subjetiva do nosso Gemüt, as três primeiras são refutadas pelo absurdo. Não se perceberiam dois eventos como simultâneos ou sucessivos, se a representação do tempo não servisse de fundamento. Tempo e espaço não são conceitos genéricos, que se "dividem" em espécies; são um singular coletivo. São grandezas infinitas; só há um tempo e um espaço. 0 acento é posto sobre o caráter de pressuposição.

A Analítica transcendental trata da constituição dos objetos. O "esquematismo" é a aplicação dos conceitos ao objeto por meio da imaginação. A esquematização das doze categorias (quatro grupos de três) toma corpo nos "princípios": axiomas da intuição, antecipações da percepção, analogias da experiência e principios da modalidade. Mais ricas quanto à determinação transcendental do tempo são as analogias da experiência. Todos os fenômenos são submetidcs a priori a regras que determinam suas relações no tempo - só percebemos objetos "no tempo".

Os três modos do tempo são a permanência, a sucessão e a simultaneidade, correspondentes às categorias da substância, da causa e da comunidade. A permanência é um modo do tempo; a simultaneidade e a sucessão são as únicas relações no tempo. Para que o tempo não se reduza a uma seqüência de aparições e desaparições, requer-se que o tempo dure mesmo. Mas só reconhecemos isto observando o que dura nos fenômenos (substância) e o que muda (acidentes).

O princípio da sucessão no tempo confere à noção de ordem no tempo a precisão de ser regular. Há duas espécies de sucessão: a que repousa sobre uma relação objetiva entre as aparências (causalidade) e a que admite o arbitrário, como a descrição duma casa (posso ir da direita à esquerda ou vice-versa). A simultaneidade é a existência do diverso no mesmo tempo. Esta simultaneidade só é percebida por ocasião da ação recíproca.

Fazendo um comentário muito genérico: o que chama a atenção é a miséria filosófica da concepção kantiana de substância, causalidade e comunidade. Tudo é determinado pelo tempo e este, por sua vez, é determinado pela construção da Física newtoniana. Então, substância é simplesmente o que dura; causalidade é simplesmente sucessão regular; comunidade é simultaneidade entre instantes quaisquer.

O sentido do transcendental kantiano é estabelecer as condições da objetividade. O sujeito.se esgota em fazer que haja objeto. A idealidade transcendental do espaço e do tempo tem por outra face a sua realidade empírica, articulada pelas ciências. As analogias da experiência fornecem o aparelho conceitual que deve ex- 
plicar a Natureza. A teoria da modalidade (o quarto grupo das categorias: possibilidade, realidade e necessidade) ajunta o princípio do fechamento, da limitação. Por isto, o tempo, de caráter subjetivo, é também o tempo da natureza, cuja objetividade é definida pelo aparelho categorial do espírito. Na concepção do tempo, Kant reconduz a Aristóteles. As contribuições de S. Agostinho, a começar pelo presente existencial e reflexivo, são abafadas sistematicamente.

\section{$4-$ Husserl}

No decorrer da História da Filosofia, as análises do tempo se complexificam; por isto, o nosso resumo é cada vez mais deficiente.

Husserl pretende fazer aparecer o tempo por meio do método fenomenológico: cf. Lições de fenomenologia da consciência íntima do tempo. Íntima significa a priori, supõe a "redução", o colocar-fora-de-circuito da atitude natural.

Husserl retoma algumas idéias de S. Agostinho sobre o tempo, mas as analisa e articula de modo mais rigoroso e - paradoxalmente - mais confuso, de modo que o leitor se sente perdido.

Falando em geral, Husserl luta contra Brentano e Kant, procurando mostrar que não se requer um laço extrinseco (a imaginação) à série dos "agora" para engendrar uma duração. $\mathrm{O}$ acento é posto sobre a continuidade.

Pode-se falar em três descobertas de Husserl: a descrição do fenômeno da retenção e da protensão, a distinção entre retenção (lembrança primária) e relembrança (lembrança secundária) e a teoria do fluxo da consciência.

Para explicar a retenção o exemplo explorado é o som. É um objeto sentido, um "objeto-tempo" (Zeitobjekt). O "agora" não se contrai no instante pontual, mas comporta uma intencionalidade longitudinal: retenção do que justamente (soeben) passou e protensão à fase iminente. Caindo no passado, o objeto-tempo se enfraquece aos poucos. Reter é ter em conjunto o presente pontual (Jetztpunkt) e as retenções agarradas a ele, num desafio à lógica do mesmo e do outro (persistir mudando). Enquanto na dimensão horizontal os instantes se sucedem, há uma descida à profundidade, onde persistem. A retenção é um presente alargado que assegura a continuidade do tempo e a difusão progressivamente atenuada da intensidade do ponto-fonte.

A lembrança primária é uma modificação da impressão, não a sua diferença. Somente quando o pensamento corta, abstratamente, o fluxo retencional, o presente, o passado e o futuro parecem excluir-se. $\mathrm{Na}$ lembrança secundária reproduzimos um objeto-tempo - não "reconstruimos" o passado na historiografia. Ouvi uma melodia ontem e a reproduzo agora, depois duma noite de sono. A relembrança dá o recuo da livre reflexão, dá à re-presentação uma articulação. A continuidade é garantida por um recobrimento: a semelhança entre o retido e o relembrado surge duma intuição. A relembrança tem pretensão de verdade: que isto aconteceu de fato. Esta segunda intencionalidade é uma réplica (Gegenbild) da intencionalidade logitudinal da retenção. O presente realiza as antecipações do passado rememorado. Daí o fluxo unitário do vivido, o "encadeamento do tempo". Na descida contínua ao passado se constitui um tempo fixo, objetivo, idêntico; mas, contra Kant, a forma do tempo não se superpõe ao puramente diverso. 
Para fundamentar a continuidade, Husserl introduz o estranho conceito de hilética (hyle = matéria) da consciência. $\mathrm{O}$ que pode ser esta matéria da intencionalidade, abstraindo da forma? E mais difícil ainda é compreender o fluxo da consciência, constitutivo do tempo. O que pode significar que o fluxo da consciência constitui a sua unidade? O autor apela à evidência: "Vede!" Mas também reconhece: "Para tudo isto os nomes nos faltam". Em lugar de conceitos, surgem metáforas: fluxo, decorrer, durar...

\section{5 - Heidegger}

Parece que Ser e Tempo resolve as divergências entre os autores anteriores, porquanto coloca um novo solo. O referente é o homem enquanto ser-aí (Dasein), que é, essencialmente, ser-no-mundo. Então o tempo é ao mesmo tempo tempo do ser-aí e do mundo. Importantes são os seguintes temas: a unidade ek-stática das três dimensões do tempo e os niveis da temporização: a temporalidade fundamental, a historialidade e a intra-temporalidade.

Diferentemente das coisas, o ser-aí se caracteriza pelos "existenciais": ser-nomundo, projetar, estar-lançado-ao-mundo, estar-decaído, poder-ser... resumidos na Sorge (cuidado). A Sorge é ser-antes-de-si (sich vorweg), buscando um ser-umtodo (Ganzsein). No Ser e Tempo, o que dá uma clausura interna ao ser-aí é o serpara-a-morte, que é a possibilidade mais própria (eigenste) do ser-aí. 'Enquanto Heidegger insiste no ser-para-a-morte, há uma ruptura entre o tempo mortal, o tempo histórico e o tempo cósmico.

A Sorge possibilita a experiência humana. Em vez de "futuro" Heidegger fala em "por vir" (Zu-kunft): vir a si mesmo segundo as possibilidades mais próprias. Em vez de "passado", o autor fala em "ter-sido". Uma resolução antecipante é tomar sobre si uma dereliç̧ão (Geworfenheit), o "ter-sido-lançado". (Nota: a língua alemã diz ich bin gewesen, literalmente: eu sou sido). Então a definição de futuro é esta: "Autenticamente por-vir é o ser-aí autenticamente tendo-sido" (p. 326, no original). $\mathrm{E}$ a definição geral de temporalidade é esta: "Este fenômeno unitário dum por-vir que, tendo sido, torna-se presente, chamamos a temporalidade" (ibid.).

O presente é a modalidade da temporalidade, de que a autenticidade é a mais dissimulada. É o tempo da preocupação (besorgen) com as coisas dadas (vorhanden) ou manipuláveis (zuhanden); é estar alienado de si. Só na antecipação do fim e na apropriação do estar-lançado o presente se torna autêntico, se torna tornarpresente (Gegenwärtigen).

A temporalidade é a unidade articulada do por-vir, do ter-sido e do tornar-presente. O "por" do "por-vir", o "já" do "ter-sido" e o "junto de" da preocupação marcam a dispersão que cunha a articulação unitária. "A temporalidade é o 'fora-de-si' (Ausser-sich) originário, em si e para si" (p. 329). Não se deve confundir isto com a distentio agostiniana, em que o espírito se "espicha" para "agora" exteriores um ao outro. O tríplice ek-stase de Heidegger parece incompreensivel racionalmente. Com efeito, o que pode ser esta exteriorização, se qualquer exteriorização sobre a linha do campo cósmico é considerada como derivada e como nivelamento? Resta um jogo de possibilidades, cuja relação com o tempo é enigmática, é um nevoeiro conceitual. 
A historialidade (Geschichtlichkeit) acrescenta à temporalidade primordial o estiramento (Erstreckung) entre o nascimento e a morte e a idéia de "coesão da vida" (Zusammenhang des Lebens, de Dilthey). A historialidade não é simples sucessão: que o nascimento já passou, que a morte ainda não chegou. O ser-aí historial constitui o seu ser verdadeiro como estiramento que envolve o seu começo e o seu fim. Neste estiramento o ser-aí deve manter uma constância a si (Selbst-Ständigkeit).

Heidegger quer resistir a duas tendências da historiografia atual: a) pensar a História apenas como um fenômeno público; b) desligar o passado do futuro. 0 ser-aí tem cada vez (je) a sua história, dirigida pela Sorge e pelo ser-para-a-morte (Schicksal), mais ou menos independente da destinação comum do seu povo (Geschick). Só à luz do presente e do futuro a pesquisa do passado tem sentido, descobrindo nele as potencialidades mais íntimas. $\mathrm{O}$ que não fica claro é a passagem da historialidade singular a uma história comum. Heidegger certamente fala do existencial "ser-com" (Mitsein), mas no Ser e tempo apenas destaca as formas decaidas do "a gente" (man).

A análise da temporalidade é uma repetição ou recapitulação da análise do ser-aí. A repetição é o retorno às possibilidades do ser-aí tendo-sido-aí. Restitui o primado da resolução antecipante no coração mesmo do abolido (na sua facticidade), do "não mais"; abre no passado potencialidades não apercebidas, abortadas ou reprimidas. A historiografia autêntica supõe a análise existencial, o histórico supõe o historial. O que não é mais é o mundo, a que os restos do passado pertenceram. O ser-aí não é passado (vergangen), mas tendo-sido-aí (da-gewesen). Os restos do passado pertenceram como utensílios a um ser-aí; são históricos, num sentido derivado, historial-mundano, e não em virtude duma objetivação científica. Aqui Ricoeur objeta: o que é esvaziado é a problemática do traço e da distância temporal, de que ainda falaremos.

Da temporalidade fundamental deriva a intra-temporalidade. Esta é o conjunto das experiências pelas quais o tempo é designado como "dentro de que" os eventos ocorrem. A proveniência da intra-temporalidade da temporalidade fundamental é expressa por "contar com o tempo" (rechnen). Contar com o tempo, calcular o tempo, é pôr o acento sobre o tempo do mundo.

A intra-temporalidade se caracteriza pela databilidade, pela extensão e também pelo caráter público. A databilidade procede da estrutura relacional do tempo primordial, quando referida ao presente: "agora", "ainda não", "mais tarde", "não mais", "outrora"... A extensão, o lapso do tempo, é o intervalo entre um "desde que" e um "até que". "Durante" este lapso as coisas duram: durante o almoço, na última primavera... Público é um "agora" qualquer e anônimo. O tempo parece autônomo. O relógio permite ajuntar à datação uma medida precisa - pode-se "ler a hora".

A intra-temporalidade, quando absolutizada, é designada por Heidegger de "tempo vulgar". Este se caracteriza como seqüência de "agora" pontuais, cujos intervalos são medidos pelo relógio.

A crítica de Ricoeur é esta: Heidegger não mostra como se pode passar da historialidade à historiografia; mais profundamente, como passar da Ontologia existencial à Epistemologia das Ciências Humanas. Consegue mostrar que a historiografia, se quer saber o que está fazendo, pressupõe a historialidade; não conse- 
gue mostrar como a historialidade fundamenta a historiografia. Com isto também permanece confusa a relação entre o ser-aí e a existência dos outros (sociedade, humanidade).

\section{6- Hegel}

O tempo é único, é um singular coletivo. Mas se considero o conteúdo, o que se passa "no tempo", devo supor que a História é una, ou posso compreender a sua unidade? Hegel aposta na sua compreensão racional. A História se unifica e totaliza ao redor da idéia de liberdade que é, ao mesmo tempo, racional e real na autorealização do Espírito. O argumento não é nada menos do que o sistema hegeliano inteiro. Aqui vou me restringir a um texto relativamente popular: "A razão na História" (primeira parte de Vorlesungen über die Philosophie der Weltgeschichte).

"O único pensamento que a Filosofia traz é a simples idéia da razão - a idéia que a razão governa o mundo e que, por conseguinte, a história do mundo também se desenrolou racionalmente" (p. 28 - ed. de Hoffmeister). Isto rejeita a cisão entre um formalismo da idéia e um empirismo do fato. O fim último da História e do mundo é a auto-realização da liberdade. Mas isto continua abstrato enquanto não são expostos os meios, o material e a efetividade daquela auto-realização do Espírito.

A primeira concretização é a identificação do Espírito com o espirito dum povo. Mas aqui também está o ponto crítico da compreensão hegeliana da História. O Espírito do mundo (Weltgeist) passa dum espírito dum povo (Volksgeist) a outro. Mas como? Como a substituição dum espírito dum povo por outro atesta a imortalidade do Espírito do mundo? Como o Espírito é um através de particularizações múltiplas?

Quanto aos meios: a liberdade se investe num interesse. Isto contraria qualquer denúncia moralizante do pretenso egoísmo do interesse ou da paixão. "Nada de grande no mundo se cumpriu sem paixão" (p. 85). Acontece que no interesse há duas visadas: a sabida e a não sabida. $O$ indivíduo se dirige a fins determinados $e$ serve, contra a sua vontade, a interesses que o ultrapassam. A "astúcia" da razão é precisamente colocar o não visado a serviço do Espirito do mundo.

Os efeitos não visados pelo indivíduo são inscritos no interesse do povo e do Estado. Aqui está o "material" da História racional. O Estado é o lugar, a configuração histórica, onde a idéia e sua realização se unem. Para o indivíduo o destino de Alexandre, de César, de Napoleão... foi um projeto arruinado; para os interesses superiores da liberdade e seu progresso no Estado foi positivo. As paixões, sob a aparência devastadora para fora delas e suicida para elas mesmas, carregam o destino dos fins superiores. O particular deve ser destruído para que o univerval seja salvo.

A efetividade do Espírito, a sua Wirklichkeit, é uma seqüência de "etapas", um Stufengang (curso por degraus). "A prova será fornecida pelo estudo da história do mundo, pois esta não é senão a imagem e o ato da razão" (p. 36). O Stufengang, modo de temporalização da razão, não é somente uma sucessão de momentos, mas é também e principalmente um retorno a si do Espírito e do seu conceito (Rückkehr in sich selber). 
Hegel visa recobrir o trágico e o lógico. "Esta relação com o nada é o tempo, e esta relação é tal que podemos não somente pensá-la, mas é também captável pela intuição sensivel" (p. 153) - observando o Stufengang. A mudança não se opera simplesmente na superfície, como no tempo biológico, mas no conceito. A História é no essencial "a explicação do Espírito no tempo (Auslegung), como a idéia se explicita no espaço como Natureza" (p. 154). Os povos passam, mas as suas criações persistem na profundidade crescente do Espírito. O Stufengang é desdobramento e enrolamento, explicitação e retorno a si mesmo. A identidade entre a explicitação e o retorno é o eterno presente. "O que o Espírito é agora, ele era desde sempre... Os momentos que o Espírito parece ter deixado atrás de si, ele os possui sempre na sua atual profundidade. Como passou por seus momentos na História, assim deve percorrê-los no presente - no seu próprio conceito" (p. 185). O historiador se volta ao que "era", mas o filósofo discerne no passado os signos do que "é", do que tem uma existência eterna.

Deve-se criticar a afirmação central: que o filósofo pode aceder não somente ao presente que, resumindo o passado conhecido, tem em germe o futuro antecipado, mas que pode aceder ao presente eterno, que assegura a unidade profunda do passado e do futuro. A pergunta crucial é esta: o que é este Espírito que mantém juntos o espírito dos povos e o espírito do mundo? É Deus? É o homem? É o quê?

A partir desta pergunta crucial, todas as demais afirmações de Hegel começam a vacilar, a começar com a equação entre o Stufengang e o eterno presente. A noção mesma de História é abolida, quando o presente nega a sua diferença face ao passado. Ora, a consciência histórica, que caracteriza nosso modo de pensar e agir, nasce precisamente desta diferença. Não podemos mais totalizar os espiritos dos povos num único espírito do mundo. A costura não resiste à massa das análises recentes, consagradas às diferenças entre as épocas e as culturas. Quanto à efetuação do Espírito: diante de tantas vítimas dos "crimes do século 20", a idéia de reconciliação se tornou intolerável. Apelar aos "interesses superiores" do Estado tornou-se um cinismo insuportável.

Não pensamos mais segundo Hegel, mas depois de Hegel. Renunciar a Hegel é abandonar o canteiro inteiro. Não procuramos mais a fórmula segundo a qual a História pode ser pensada como totalidade. Renunciamos à pretensão de decifrar 0 enredo de todos os enredos, o enredo supremo. Confessamos a finitude da nossa compreensão: que todo pensamento tem pressupostos que ele é incapaz de recuperar e dominar; que há algo a partir do que pensamos, sem poder pensá-lo em si mesmo.

\section{II - Uma solução parcial: a poética da narração}

No capitulo anterior vimos as aporias do tempo, a começar pela aporia básica da impossibilidade de pensar juntos o tempo do mundo e o tempo da alma, o tempo objeto e o subjetivo. Com Heidegger e Hegel introduzimos o problema da História e a aporia da necessidade e impossibilidade de pensar a totalidade da História.

A esta aporética especulativa Ricoeur procura dar uma resposta poética mediante a narração. $\mathrm{O}$ tempo não se explica, ele se narra. Há duas espécies básicas 
da narração: a histórica e a fictícia. O entrecruzamento de Historiografia e ficção oferece uma refiguração da nossa experiência temporal. Surge um terceiro tempo, o tempo realmente humano, histórico. A narração refigura a condição histórica e permite elevá-la ao nivel da consciência histórica. A especulação hegeliana deve ser substituida por uma Hermenêutica, que se contenta com uma mediação imperfeita entre presente, passado e futuro e aponta, no meu entender, para uma eternidade trans-histórica.

Resumindo, de forma livre, a segunda seção do terceiro volume de Temps et récit, vamos desenvolver os seguintes temas: 1) 0 tempo histórico; 2) Historiografia e ficção; 3) a consciência histórica; 4) o presente histórico; 5) a identidade narrativa. A identidade narrativa, resumindo os temas anteriores, permite conceber a morte como passagem (vita mutatur, non tollitur) e a eternidade como o oposto dialético do tempo.

\section{1-O tempo histórico}

A Historiografia une o tempo vivido e o tempo universal, inventando e empregando certos conectores: o calendário, a noção de seqüência de gerações e os arquivos, documentos e traços.

O calendário tem três características: a) Há um acontecimento fundador, julgado abrir uma nova era; é o momento axial, o ponto zero a partir do qual os eventos são datados. Para os cristãos é o nascimento de Cristo que (por motivos pelo menos pragmáticos) é aceito universalmente como base da datação, p. ex. no ano 322 a. C. ... no ano 1789 d. C. ... b) Pode-se percorrer o tempo nas duas direções: do presente ao passado ou vice-versa. c) Fixam-se unidades de medida: ano, mês, dia, hora...

É fácil de ver que o tempo histórico tem um parentesco com o tempo físico: é um contínuo uniforme, ilimitado, segmentável, fonte de instantes quaisquer, é mensurável, é "escorado" em fenômenos astronômicos. Mas também tem um parentesco com o tempo vivido: o presente é distinto do instante qualquer. Sem o presente não podemos dar um sentido aceitável à idéia de acontecimento novo. Se não tivéssemos a experiência da retenção e da protensão, não teríamos a idéia duma série de eventos. A medida objetiva do tempo se enxerta sobre a experiência que S. Agostinho descreveu como encurtamento da espera e alongamento da lembrança. Os acontecimento recebem uma posição no tempo: p. ex. 30 anos depois da Tomada da Bastilha (supõe-se que se sabe datar esta Tomada com relação ao momento axial do nascimento de Cristo). O mesmo ocorre com os acontecimentos da minha vida: quando eu tinha 7 anos... Podemos convocar reuniões com antecedência e exigir que todos compareçam.

A seqüência das gerações é um conceito sociológico com "escoramento" biológico. Designa a cadeia dos agentes históricos, vindo os vivos ocupar o lugar dos mortos. A partir da duração média da capacidade de procriar (na mulher), uma geração dura 30 anos. Estamos separados de Cristo por 66 gerações. É muito? Do ponto de vista do tempo da Astrofísica, somos quase contemporâneos; do ponto de vista cultural há uma importante distância temporal. 
A sequiência das gerações é a combinação entre influências recebidas e exercidas, entre transmissão do adquirido e abertura de novas possibilidades. Pertencer à mesma geração é ter a propensão (não determinação única) a pensar, sentir e agir de certa maneira. Ser contemporâneos é "envelhecer juntos" (Alfred Schutz). É a participação pré-reflexiva num destino comum. Portanto, a seqüência das gerações é uma estrutura intermediária entre a exterioridade física e a interioridade psiquica do tempo.

A morte tem na Historiografia uma significação ambígua, onde se misturam a referência à intimidade da mortalidade (morte própria) e a referência ao caráter público da substituição dos mortos pelos vivos (morte anônima). A morte só é tratada por alusão, em benefício de entidades de duração maior: o povo, a instituição, etc.

Os arquivos são os "depósitos autorizados" duma instituição, depois de discernir o que deve ser conservado e o que deve ser destruído; são bancos de dados, para alargar a memória coletiva. Os documentos são a garantia, a prova material do que de fato se passou. São monumentos, quando têm a finalidade explícita da comemoração (ou da execração, p. ex. o campo de concentração de Dachau, em München). A fonte de autoridade do documento é o traço (vestígio). Mas o que é propriamente um traço?

Dum lado, o traço é visível aqui e agora; doutro lado, há traço porque antes um homem passou por lá, fez isto ou aquilo. O traço indica o passado sem o mostrar. Combina causalidade e significação, é efeito signo.

Os conectores - calendário, traço .. - são criações, resultantes do cruzamento da perspetiva fenomenológica e da cósmica sobre o tempo. O calendário é uma colisão negociada, o traço é uma contaminação regulada. Dum lado, o tempo da Sorge se arranca à fascinação dum tempo que ignora a nossa mortalidade; doutro lado, o tempo dos astros nos livra do aguilhão da preocupação imediata e mesmo à idéia da nossa morte. $\mathrm{E}$, contudo, sobre o quadrante do meu relógio surge às vezes, em letras de luto, o memento mori (lembra-te que vais morrer). No traço há uma contaminação regulada entre o tempo da alma e o tempo do mundo. Seguir o traço é uma maneira de contar com o tempo: o tempo que passou entre a passagem do "objeto" da pesquisa histórica e nós; é decifrar o estiramento do tempo. Para isto o lapso de tempo deve ser submetido ao cálculo e ao tempo público.

\section{2 - Historiografia e ficção}

Vamos, primeiramente, distinguir entre ficção e Historiografia, para depois uni-las numa complementaridade dialética, entrecruzá-las (termo muito apreciado por Ricoeur).

O narrador de ficção (epopéia, tragédia, drama, romance, novela) se liberta da obrigação do historiador de se dobrar aos conectores e explora os recursos do tempo fenomenológico que ficam inexplorados na narração histórica. Uma das técnicas é a personificação. Cada personagem tem as suas "cavernas privadas". Também se explora imaginativamente o limite superior do tempo, a eternidade. Esta é dita de várias maneiras (cf. A montanha mágica, de Thomas Mann). 0 tempo é considerado, ora como destruidor, ora como "artista" que "trabalha muito lentamente" (cf. A busca do tempo perdido, de Marcel Proust; já Aristóteles dizia que o tem- 
po é um "auxiliar benéfico"). Pelas variações imaginativas se revela um eidos como invariante, como um tipo-ideal.

O recurso aos documentos é uma linha divisória entre História e ficção. O historiador está submetido ao que foi, tem uma dívida. Ricoeur fala em representância. Esta não consiste em criar uma imagem mental da coisa ausente, mas em fazer uma reconstrução que, interpretando traços, procura "corresponder" ao passado.

Em termos de Filosofia da História se pode distinguir três concepções da relação da narração histórica com o passado:

a) Concepção identitária (R. G. Collingwood, The Idea of History): dissocia a face "interior" do evento (pensamento, no sentido amplo da palavra) e a face "exterior" (mudanças físicas); toma o pensamento do historiador como re-pensar; este re-pensar é numericamente idêntico ao primeiro pensar. Portanto, há uma desdistanciação, uma identificação com o que foi. O passado é inteligivel como persistindo no presente. A História é "reefetuação" (reenactment) do passado. "Toda história é a reefetuação do pensamento passado no próprio espírito do historiador" (cit. na p. 208). No traço o caráter de passado é abolido pelo ato intemporal de re-pensar. A idéia hegeliana da autoprodução do Espírito é especificada como reefetuação.

Mas, então, o historiador não conhece o passado, mas somente o seu pensamento sobre o passado. Além disto, tanto no ato original quanto no ato reflexivo do presente há uma opacidade insuperável, que a Hermenêutica aponta e explora.

b) Ontologia negativa do passado (historiadores franceses, p. ex. Paul Veyne): faz uma apologia da diferença, produz uma estranheza contra toda familiarização. É o descentramento, contra o etnocentrismo europeu. "Os romanos foram tão exóticos quanto os tibetanos". A curiosidade sobrepuja a simpatia ou empatia. Como o evento é posto em posição de desvio (écart) face ao discurso, pode-se falar duma ontologia negativa.

Mas deve haver algo de positivo na persistência do passado no presente. A curiosidade ainda supõe certa familiaridade.

c) Uma abordagem tropológica (Hayden White, Tropics of Discourse). Os tropos empregados são a metáfora, a metonímia, a sinédoque e a ironia. A metáfora tem uma vocação explicitamente representativa. Os outros tropos corrigem a ingenuidade da metáfora. A correção mais forte é a ironia: introduz uma nota negativa, lembra a natureza problemática da linguagem no seu conjunto. O percurso completo autoriza a falar duma estrutura tropológica da consciência. Há um elemento trópico em todo discurso. As coisas sempre podem ser expressas de outro modo. A complementaridade entre a Retórica dos tropos e a Lógica dos modos de explicação substitui a distinção demasiado simplista entre fato (informação) e interpretação (explicação). Entre narração e cursos dos eventos não há uma relação de reprodução, mas uma relação tropológica, metafórica ou analógica.

Também a ficção é reveladora: traz à luz traços dissimulados, mas já desenhados na experiência. E é transformadora: muda a vida pela apropriação. A configuração do texto, recebida pela leitura, refigura a experiência. A leitura é um drama de concordância discordante. O leitor crê na obra a ponto de nela se perder - ilusão no sentido de crer-ser. A "boa" leitura admite certo grau de ilusão e assume o desmentido dum plus de sentido. $\mathrm{O}$ autor partilha com o leitor um repertório do fami- 
liar e usa a estratégia da desfamiliarização. P. ex., o romance Dom Quixote supôe uma familiaridade com o mundo da cavalaria e produz um choque... A obra é uma mediação entre o horizonte do passado e o horizonte do presente. Por isto, lectio transit in mores (Erasmo).

A libertação da ficção face às coações históricas (prova documental) não é a última palavra. Há uma necessidade interior, uma liberdade para... Daí o sofrimento do artista, procurando expressar a sua visão do mundo da maneira mais perfeita. Para além da confusão e da alienação, a leitura cria uma relação analógica entre as expectativas criadas pelo texto e as expectativas trazidas pelo leitor. Paradoxo: quanto mais o leitor se irrealiza na leitura, tanto mais profunda será a influência da obra sobre a realidade pessoal e social.

A imaginação também tem um papel na narração histórica, sem enfraquecer a visão "realista". O ter-sido não é observável. O traço é efeito-signo. Só se vê o valor do traço figurando-se o contexto da vida, social e cultural, o mundo (Heidegger) que hoje falta ao redor da relíquia. $\mathrm{O}$ caráter ambíguo do passado nos arrasta ao jogo do mesmo, do outro e do análogo. Há um duplo perigo. Dum lado, apagar a fronteira entre a ficção e a História; doutro lado, julgar que a linguagem do historiador se pode tornar inteiramente transparente, a ponto de deixar os fatos mesmos falar. A análise tropológica é uma explicitação da analogia. O passado, em certo sentido, deve ser reefetuado de modo identitário; mas também está ausente das nossas construções. $\mathrm{O}$ análogo retém a força da reefetuação $e$ da colocação à distância, na medida em que o ser análogo é ser e não-ser, é ser-como. Voltamos à significação paradoxal do traço: significa, sem fazer aparecer. $O$ ter-sido não é observável, só é memorável. A representância sintetiza a redução ao mesmo, o reconhecimento da alteridade e a apreensão analógica.

Uma "ficcionalização" da História são os eventos "epoch-making", com o seu poder de fundar ou reforçar a consciência da identidade duma comunidade. Em muitos assuntos, a neutralidade do historiador não é possivel, nem desejável. $\mathrm{Na}$ Biblia (Deuteronômio) ocorre freqüentemente o imperativo: "Zakohr, lembra-te!" Há eventos horrendos que é necessário não esquecer jamais, p. ex., o "holocausto" de seis milhões de judeus. É a história das vítimas (não tanto dos vencidos, porque estes queriam vencer). Só a vontade de não esquecer pode fazer que tais crimes não se repitam.

Há uma "historização" da ficção. A narração ficional imita de certa maneira a narração histórica. Narrar é narrar como se tivesse ocorrido. $\mathrm{O}$ enredo deve ser provável, verossímil, possível. A Historiografia cuida do passado efetivo; a poesia, do possível. A verdadeira arte não fotografa a superfície do real, mas os possiveis enterrados no real, "o tesouro escondido no campo".

\section{3- A consciência histórica}

A nossa estratégia é partir do futuro, da história por fazer; depois, ver a dialética do futuro e do passado e sua troca no presente. O presente não é só presença, também é iniciativa.

Reinhart Koselleck (Vergangene Zukunft) investiga a polaridade entre o espaço de experiência e o horizonte de expectativa. Experiência (Erfahrung), é estranheza 
superada, é aquisição tornada habitus. Espaço é a possibilidade de ajuntar e estratificar os conteúdos adquiridos. A expectativa inclui vontade, desejo, cuidado, esperança, cálculo, curiosidade... Horizonte é potência de desdobramento. A experiência tende à integração, a expectativa tende a estourar a perspectiva.

A partir destas meta-categorias podemos reavaliar a Aufklärung. Esta se caracterizou por três topoi: a) a crença de que a época presente abre sobre o futuro a perspectiva duma novidade sem precedente; b) a crença de que a mudança para o melhor se acelera; c) a crença de que os homens são mais e mais capazes de fazer a sua história. Portanto, tempos novos, aceleração da História e dominação da História. Isto acarretou a crença no progresso e a luta contra tudo que o retarda. Correlativamente, o espaço da experiência se estreitou e esfriou a autoridade das tradições.

No fim do século 20 se constata o declínio destes topoi (pós-modernidade). Não temos certeza que a Época das Luzes foi um progresso e em que sentido. Muitos desastres e desordens fazem descrer na aceleração da História. Há um intervalo crescente entre o espaço de experiência e o horizonte de expectativa. A realização do fim da História (o homem esclarecido e a humanidade reconciliada?) parece recuar para um futuro mais e mais longínquo e incerto, que foge mais depressa do que nós avançamos. Quando a expectativa não se consegue fixar sobre um futuro determinado, escalonado por etapas discerniveis, o presente se cinde entre um passado ultrapassado e um futuro último que não suscita nenhum penúltimo assinalável. É a crise, segundo Koselleck.

A modernidade é um "projeto inacabado". A tensão entre horizonte e espaço deve ser preservada para que haja história. Expectativas puramente utópicas impedem a ação sensata por falta de ancoragem na experiência em curso, são incapazes de formular um caminho praticável. As expectativas devem ser determinadas, se devem suscitar um engajamento responsável. Requerem-se projetos intermediários. Doutro lado, é preciso reabrir o passado, reavivar nele potencialidades não cumpridas. É preciso tornar nossas expectativas mais determinadas e nossa experiência mais indeterminada. Só expectativas determinadas têm sobre o passado o efeito retroativo de o revelar como tradição viva.

Somos afetados pelo passado. "Os homens fazem sua própria história, mas em circunstâncias encontradas, dadas, transmitidas" (Marx, cit. p. 309). Os que crêem ser os agentes mais criativos da História, não a sofrem menos. É o que Gadamer desenvolve na obra Verdade e método, com a sua tese central da "consciência de ser exposto à eficiência da História".

Deve-se distinguir entre tradicionalidade, as tradições e a tradição.

A tradicionalidade é o estilo de encadeamento da sucessão histórica. É um transcendental da Filosofia da História. Há uma dialética entre a eficiência do passado que sofremos e a recepção do passado que operamos pela leitura. A distância temporal é separação e mediação. Devo distanciar para compreender. Entre o saber absoluto que desconhece os horizontes (Hegel) e a multidão de horizontes incomensuráveis (Nietzsche), há uma fusão de horizontes (Gadamer): do horizonte do passado e do presente. É projetando um horizonte histórico que provamos, na tensão com o horizonte do presente, a eficiência do passado. 
$A$ tradição significa que a distância temporal não é um intervalo morto, mas uma transmissão de sentido. É a troca entre o passado interpretado e o presente interpretante.

As tradições são o conteúdo do passado. Jamais estamos na posição absoluta de criadores, mas sempre, inicialmente, na situação de herdeiros. A linguagem é a grande instituição que desde sempre nos precede. Linguagem significa o sistema da língua $e$ as coisas ditas, entendidas e aceitas. A efetividade do passado é, em grande parte, a dos textos, "janelas" abertas sobre a vasta paisagem do passado, na dimensão lingüística. $O$ passado nos interroga na medida em que o interrogamos; responde-nos na medida em que lhe respondemos.

Toda proposição de sentido é uma pretensão de verdade. 0 que recebemos são crenças, convicções. Para Gadamer a pretensão de verdade é uma autopresentação das "coisas mesmas". Mas, fora do nosso pré-conceito como estrutura de précompreensão, a "coisa mesma" não se pode fazer valer. Autoridade é superioridade, é aumento (augere), a que corresponde, não a obediência cega, mas o reconhecimento desta superioridade.

O metodologismo é a pretensão duma consciência julgadora, erigida em tribunal da História e imune a todo preconceito, constituinte e dona do sentido. Mas a apreensão ativa dum sentido e a liberdade face aos conteúdos recebidos não são a primeira atitude. "Toda hermenêutica histórica deve começar por abolir a oposição abstrata entre tradição e ciência histórica, entre o curso da História e o saber da História" (Verdade e método, p. 267, no original). São as tradições rivais que introduzem na tradição uma "polaridade entre familiaridade e estranhesa; é sobre ela que se funda a tarefa da Hermenêutica" (p. 279). É o fato da má-compreensão que provoca a Hermenêutica. A questão propriamente crítica é "a distinção a operar entre os preconceitos verdadeiros que guiam a compreensão e os preconceitos falsos que trazem a não-compreensão" (p. 282).

Há uma dialética entre ser afetado pelo passado e antecipar um horizonte de expectativas. Esta dialética abre no passado, julgado abolido, possibilidades esquecidas, tentativas reprimidas. Este potencial liberado pode dar carne e sangue às nossas expectativas, p. ex., ao ideal duma comunicação sem coação e sem limites e reinvestir-se na História efetiva, constituindo o presente histórico.

\section{4-O presente histórico}

S. Agostinho define o presente pela attentio, que ele também chama de contuitus. Para libertar o presente do prestígio da simples presença, Ricoeur o liga à iniciativa, uma categoria do agir. Então o presente não consiste somente em ver as coisas que estão na minha presença, mas consiste principalmente em agir, começar, dar às coisas um curso novo.

O corpo próprio - como mostraram Merleau-Ponty e outros - é o mediador mais originário entre o curso do vivido e a ordem do mundo; precede todos os conectores do tempo histórico. $\mathrm{O}$ corpo próprio, a carne, desafia a dicotomia entre 0 físico e o psíquico, entre a exterioridade cósmica e a interioridade reflexiva. A experiência básica é a do "eu posso", p. ex., levantar o meu braço. É uma "ação de base" - paralela ao enunciado de base. A carne é o conjunto dos meus poderes e 
não-poderes; correspondentemente, o mundo é o conjunto dos utensilios, dóceis ou rebeldes.

Das ações de base, que sabemos fazer sobre a base duma simples familiaridade com os nossos poderes, se distinguem as ações derivadas. São eventos que ocorrem porque realizamos uma ação de base: p. ex., purifico o ar do meu quarto (ação derivada), abrindo a janela (ação de base, que propriamente é uma série: levantar-me, extender o braço, agarrar, puxar...). Mas mesmo as conseqüências longínquas da nossa ação não são simplesmente objetos de observação. Não é na mesma atitude que observamos o que acontece e fazemos algo acontecer. Daí resulta que só podemos analisar objetivamente sistemas finitos, determinismos parciais. A extrapolação ao universo inteiro nos excluiria como agentes. Se o mundo é a totalidade dò que é observável, do que é "o caso", o fazer não se deixa incluir nesta totalidade. $\mathrm{O}$ fazer faz que a realidade não seja totalizável. Em outros termos, sou livre. No quadro da teoria dos sistemas, a noção equivalente de iniciativa é a intervenção. É a capacidade de unir o poder-fazer (ação de base) com as relações internas dum sistema (Natureza, organismo, psiquismo, sociedade...). É intervindo que descubro as relações causais, vigentes na Natureza.

No plano histórico a intervenção é o ponto nodal do modelo de explicação quasi-causal. Este modelo articula segmentos teleológicos e nômicos, fases intencionais e físicas. O presente é sui-referencial. Os atos de fala levam a linguagem para a dimensão da ação; doutro lado, o agir humano está intimamente articulado por signos, normas e avaliações que o situam na dimensão simbólica. $\mathrm{O}$ ato de fala engaja o locutor, p. ex., a promessa. Manter a palavra é fazer que a iniciativa tenha seqüência. A iniciativa reveste uma significação ética. O presente histórico é o espaço comum de experiência, o espaço público, porque a promessa tem uma caráter dialógico, faz parte do pacto social.

A nossa época se caracteriza, ao mesmo tempo, pelo afastamente do horizonte de expectativas e pelo estreitamento do campo de experiência. Isto faz do nosso tempo um tempo de crise, que exprime a distenção da condição histórica entre utopia e depósito morto. A nossa tarefa é impedir que a tensäo se torne cisma: procurar os primeiros passos e libertar as potencialidades do passado.

O nosso presente histórico é de extrema complexidade. É um tempo de crise (Koselleck), percebida mais ao nível do sentimento do que da razão. Uma das características positivas é o interesse pela Ética, no sentido duma Ética universal, portanto, ligada à Política: cf. a grande repercussão das obras de Habermas e Apel. Outra característica é uma intensa pesquisa das raizes culturais de cada povo e uma crescente responsabilidade pelo futuro (Ecologia). O que nos falta é integrar nos projetos de "qualidade de vida" a imaginação, com os seus elementos ideológicos e utópicos, como tenta Ricoeur (principalmente no livro Ideologia e utopia). O primeiro passo duma "conversão" não é a decisão, mas a imaginação. É preciso "ver" um novo modo de ser, individual e comunitário. Só quem está "fascinado" se decide realmente. Mais do que isto, é preciso buscar os fundamentos metafísicos e teológicos. "Se Deus não existe, tudo é permitido" (disse brutalmente Dostoievski), nem é possível uma fundamentação última da Ética, como sempre se viu na História, até Kant inclusive. Mas, antes de falar do "metafísico" e do 'teológico", portan- 
to, da eternidade, é preciso recolher o ensinamento básico deste longo desvio pelo tempo histórico: a identidade narrativa.

\section{$5-A$ identidade narrativa}

A atividade mimética da narração é a invenção dum terceiro tempo, pela construção de conectores. Há um entrecruzamento da visada da História e da ficção. Deste entrecruzamento surge uma unificação dos diversos efeitos de sentido, uma unidade narrativa. A identidade narrativa é uma categoria da prática; responde à pergunta: quem fez tal ação? É o suporte da permanência do nome próprio, é contar a história duma vida. A diferença entre idem e ipse é a diferença entre uma identidade substancial ou formal e a identidade narrativa que é dinâmica. O simesmo é refigurado pela aplicação reflexiva das configurações narrativas. $O$ sujeito é leitor e escritor da sua própria vida. A vida é refigurada pelas histórias, verídicas ou fictícias, que um sujeito conta sobre si mesmo. O si-mesmo do conhecimento de si não é o eu egoísta ou narcisista, de que as Hermenêuticas da suspeita denunciam a hipocrisia, a ingenuidade, o caráter ideológico, o arcaísmo infantil ou neurótico. O si-mesmo é o fruto duma vida examinada, purificada pelos efeitos catárticos das narrações, um si-mesmo instruído pelas obras de cultura que um sujeito aplicou a si mesmo. Freud fala de perlaboração (Durcharbeitung). A cura consiste em substituir as migalhas de História, ininteligíveis e insuportáveis, por uma História coerente e sensata, em que o sujeito pode reconhecer a sua ipseidade. $\mathrm{O}$ mesmo vale das comunidades históricas, p. ex., Israel. Nenhum povo foi tão apaixonado pelas histórias que ele mesmo contou sobre si mesmo. Tirou a sua identidade da recepção dos textos que ele mesmo produziu. Há uma relação circular ou em espiral entre um caráter e as narrações que, ao mesmo tempo, expressam e moldam este caráter.

Mas a identidade narrativa, fruto duma Poética, só é uma solução quando está unida à Ética. Requer-se a decisão, que faz da responsabilidade ética o fator supremo da ipseidade. Certo, a narratividade não está despojada da dimensão normativa. Pertence ao leitor, novamente agente, iniciador da ação, escolher entre as múltiplas proposições duma "vida boa".

Surge a pergunta: avançamos de fato no conhecimento do tempo, quando introduzimos a História, a consciência da História e seu fruto mais valioso, a identidade narrativa? Ou, pelo contrário, o tempo não se mostra mais e mais inescrutável? Não é mais fecundo considerar, conjuntamente, o tempo e a eternidade, como se fazia na tradição grega e medieval?

\section{III - A eternidade}

\section{1 - O desejo de eternidade}

Aristóteles divide todos os seres em dois grandes grupos: os seres móveis e os imóveis (não: os sensíveis e os supra-sensíveis). Móvel significa sujeito ao movimento. Há quatro espécies de movimento (mudança): local, quantitativo, qualitativo e substancial (geração e corrupção). Como os astros só admitem o movimento 
local, que é o mais superficial, valem como seres imóveis; móveis são os seres sublunares.

Deus, para Aristóteles, é o ser absolutamente imóvel, o primeiro motor imóvel. É "motor", mas não move como causa eficiente; para isto deveria mover-se. Só move como causa final, como o amado "move" o amante. A sua simples presença faz com que os outros seres se movam, não para atingi-lo, mas para imitá-lo. (Já Platão dizia que o tempo é "uma certa imitação móvel da eternidade"). É melhor ser imóvel. Mas os seres que por natureza são móveis, porque constituídos de ato e potência, devem de fato mover-se. Podemos dizer que têm desejo de eternidade.

Também Hegel quer atingir o "eterno presente". O ponto de partida não é a análise dos seres individuais, mas a questão da unidade e da totalidade da História. Se para os indivíduos humanos, o passado não é mais e o futuro ainda não é, o Espírito resume o presente, o passado e o futuro na sua profundidade. $O$ Espírito supera a distinção entre o espaço de experiência, o horizonte de expectativa e a força do presente. A História é inteiramente permeável à luz do conceito. O tempo cósmico é engulido pelo tempo psíquico. Isto recorda o verso de Vinicius de Morais: "O amor é eterno enquanto dura".

Heidegger, no Ser e tempo, parece fechar qualquer saída para a eternidade. O próprio tempo é finito. O ser-aí (homem), movido pelo Sich-vorweg da Sorge, busca ser um todo, ser integral (Ganzsein). Isto implica o ser-para-a-morte. Na antecipação resoluta (Entschlossenheit) do ser-para-a-morte, os três ek-stases do tempo são o mais possivel unidos. Certo, "a temporalidade é o 'fora-de-si' originário em si e para si" (p. 329). Mas, na resolução autêntica, a temporalidade mais ajunta do que dispersa. Esta idéia repercute no romance de Simone de Beauvoir, Todos os homens são mortais: se a vida fosse interminável, seria insuportável; a vida só tem "graça" porque é breve; a vida só é "séria", porque as chances não se repetem.

A partir de Os problemas fundamentais da Fenomenologia, Heidegger não fala mais do ser-para-a-morte como daquilo que totaliza o tempo ek-stático. O sentido da temporalidade é a possibilitação da compreensão do ser. $O$ ek-stase fornece um horizonte, um "em direção de..." A intencionalidade humana é pensada num sentido francamente ontológico. E Heidegger começa a falar da diferença ontológica entre o ser e o ente. Mas... o ser não é o eterno da Metafísica tradicional; o ser acontece - é Ereignis. Mas no meu entender, tanto o desejo de ser integral como a diferença ontológica permitem uma reinterpretação no sentido de que a finitude não se confunde com o Positivismo chato de quem afirma que com a morte tudo acaba.

O homem tem o desejo de ser imortal. Já os gregos invejavam os deuses imortais. O homem é incapaz de aceitar tranqüilamente "a dura vitória da espécie sobre o indivíduo" (Marx). Claro, deixar descendentes é, de algum modo, sobreviver; mas não atinge a pessoa na sua ipseidade. Grandes artistas querem ser imortais numa obra que seja aere perennius (mais perene que o bronze - do poeta latino Horácio). O que não é explicado pela "imortalidade" nos descendentes biológicos e nas obras culturais é a terrivel angústia perante a morte. Quando Homero diz que "os homens morrem como caem as folhas das árvores", não é uma simples constatação, é expressão duma profunda melancolia. O homem não suporta a idéia de desaparecer totalmente. 
O suicídio não é uma objeção válida. Pelo contrário. O indivíduo quer "acabar 'om tudo" porque não suporta certa situação. Mas esta recusa violenta supõe a xigência dum sentido absoluto. A negação supõe uma afirmação: a expériência lo absurdo (tão explorada por Albert Camus) só é possivel porque se busca um :entido absolutamente válido que eventualmente parece bloqueado por circunstânias adversas (Bernhard Welte, sacerdote católico, amigo de Heidegger, aproveitou nagistralmente as profundas análises deste sobre a angústia, no sentido duma Heilsverständnis (compreensão da salvação).

\section{2 - Como pensar a eternidade}

\section{z) $\mathrm{O}$ mito}

O mito pensa o tempo na sua relação com o seu outro. O tempo, o chronos, é um deus que devora os seus próprios filhos: põe e retira. O chronos é aproximado to okeanos: ambos estão num movimento infatigável.

Um dos pontos de apoio das imaginações míticas sobre o tempo é a comparação entre o tempo cósmico e o tempo humano. Enquanto o tempo dos astros perdura, o tempo humano é provado como fator de instabilidade, de destruição e de morte. O tempo cósmico é representado como um círculo; tem uma organização cíclica, a que se integram harmoniosamente as sucessões das estações, a seqüência das gerações, o retorno periódico das festas. Em outras culturas (p.ex., a indu) o tempo é representado por uma roda, insensível aos desejos, ânsias e gemidos dos mortais. De tudo isto se destaca o aion (eternidade) divino, totalmente imóvel, de que o mito nada tem a dizer, a não ser a metáfora intrigante do "eterno retorno de todas as coisas".

Como a Filosofia Moderna, mais e mais, omite a questão da relação entre o tempo e a eternidade, alguns romancistas, dotados de sensibilidade e imaginação, retomaram a questão em "fábulas sobre o tempo". Ricoeur , "temps et récit", analisa longamente três romances: Mrs. Dalloway de Virgínia Woolf, $A$ montanha mágica de Thomas Mann e A busca do tempo perdido de Marcel Proust. A fenomenologia do tempo, com suas diversas "experiências", é figurada em personagens. Há momentos de extrema concentração da temporalidade, que são experiências-limites da eternidade. Exemplo marcante é o encontro do "tempo perdido" (perdido na investigação científica dos "signos") na experiência supra-temporal da Beleza, donde procede 0 elã de criar uma obra de arte que seja aere perennius. Mas o banquete do encontro, da síntese, da reconciliação é cercado pela dança dos moribundos do memento mori. A Arte é apenas um armistício, não é um "descanse em paz". "O artista, o tempo" não é solução final e o romance de Proust termina com as enigmáticas palavras dans le temps.

\section{b) A Bíblia}

O contraste entre o tempo e a eternidade, segundo a Bíblia, é bem expresso nas meditações do livro XI das Confissões de S. Agostinho. Este contraste pode revestir-se de várias tonalidades: a) sobriedade: "Mil anos são a teus olhos como 0 dia de ontem uma vez decorrido, como uma vigília da noite" (Sl 90, 4). "De eternidade em eternidade, Tu és Deus" (Sl 90, 2); b) louvor à eternidade do Verbo que 
perdura, quando nossas palavras passam: "No eterno nada passa, tudo é todo inteiro presente, enquanto nenhum tempo está todo inteiro presente"; "Os teus anos não vão nem vem... subsistem simultaneamente (simul stant) c) queixa: sob o horizonte da eternidade estável, a alma agostiniana se descobre exilada na "região da dissemelhança"; é a tristeza da finitude; d) esperança: a alma agostiniana atravessa niveis de temporalização cada vez menos "distendidos" e sempre mais "tendidos" (tensos), atestando que a eternidade pode trabalhar do interior a experiência temporal.

O Novo Testamento, de ponta a ponta, trata da relação entre esta vida e a vida "além-túmulo", entre o tempo e a eternidade. Sem querer fazer aqui uma mini-escatologia, vale destacar três temas centrais:

a) A certeza da eternidade não está ligada à natureza da alma (simplicidade), mas à Ressurreição de Cristo. O Cristianismo nasceu duma experiência forte, avassaladora, da comunidade primitiva: "O Senhor está vivo", embora tenha morrido na cruz. Entrar na eternidade é "estar com Cristo", participar do "banquete celestial". "Tuis enim fidelibus, Domine, vita mutatur, non tollitur, et, dissoluta terrestris huius incolatus domo, aeterna in coelis habitatio comparatur" (Prefácio da missa dos defuntos: pois para os teus fiéis, Senhor, a vida é transformada, não tirada, e desfeita a casa desta peregrinação terrestre, é-nos preparada no céu uma habitação eterna).

b) A eternidade pode ser feliz ou infeliz - pode ser o céu ou o inferno. Quanto a isto o Evangelho não deixa dúvidas, p.ex., o célebre texto sobre o juízo final: Mt 25, 31-46, que "queima" a consciência cristã. A Escatologia tem a tarefa de distinguir o núcleo duro da doutrina cristã e o revestimento alegórico ou metafórico. Mas a aporia básica é pensar a unidade entre a infinita justiça divina e a infinita divina misericórdia. Contra a doutrina da reencarnação (para se purificar dos pecados duma vida anterior e contra o determinismo (Calvino), deve-se invocar a seriedade da existência humana: se o homem é livre e autônomo (ipseidade), então também é responsável por seu comportamento. $\mathrm{E}$ se falha qualquer solução especulativa, resta a solução prática duma confiança na misericórdia divina, aliada ao esforço de corresponder à graça divina.

c) O Reino de Deus, que é um resuno da mensagem evangélica, já começa nesta vida. Nesta vida está em fase incoativa, depois estará na fase definitiva, em que Deus "será tudo em todos".

Estas idéias da Bíblia "dão que pensar": fornecem um material muito rico para ser articulado racionalmente e exigem esclarecimentos. Uma das perguntas que surge naturalmente é esta: o céu não é monótono - insuportavelmente monótono? Para responder, Kant introduz na eternidade um progresso ilimitado na virtude. Não há outra solução? Outra questão é a relação entre o tempo e a eternidade: em que sentido o Reino de Deus já está presente? Como a eternidade trabalha o tempo de dentro dele? Para responder, Hegel afirma o eterno presente na especulação dialética sobre a História. Não há outra solução?

\section{c) A Filosofia}

Podemos pensar a eternidade, no nível metafísico, como ato puro; e, no nível meta-histórico, como eterno presente. 
Segundo Aristóteles, Metafísica livro XII, Deus, em relação ao resto da realidade, é o primeiro motor imóvel; em si mesmo, è ato puro. $\mathrm{O}$ ato puro é noesis noeseos, pensamento que pensa eternamente e exclusivamente a si mesmo e nisto é perfeitamente feliz. O que nós fazemos, de vez em quando e com grande esforço, Deus o faz constantemente e sem fadiga. O problema é o que é "ato"?

Aristóteles inventou a teoria do ato e da potência (principalmente no livio IX) para explicar a mudança. Como é que um ente pode mudar e continuar o mesmo? Deve mudar o todo e o todo deve continuar o mesmo. A resposta aristotélica é esta: em relação ao ente em ato, o ente em potência é um não-ser, mas não sem mais, porque já é (em potência). Mas tanto "potência" quanto "ato" tem várias significações (o que torna complicado o texto em apreço). A potência pode ser ativa, passiva ou mista. Ato pode significar agir (em oposição à mera capacidade de agir) e pode ser o resultado deste agir, o efetivo, efetuado, atualizado. Deue é tanto agir (o pensar) quanto resultado (o pensamento). Como compreender isto?

Há duas espécies de agir ou de ação: a) a ação imanente, que permanece em si ou se orienta para dentro, em que o sujeito se aperfeiçoa a si mesmo; b) a ação transitiva, que sai de si mesma ou se orienta para fora aperfeiçoando (ou destruindo) um outro. A primeira espécie se destaca tanto mais quanto mais perfeito é o ente. Parece que é isto que Aristóteles quer dizer, quando afirma surpreendentemente: ter movido e mover não são a mesma coisa; ter sido feliz e ser feliz são a mesma coisa. Há um agir que não implica mudança e não se move sobre a linha do tempo cósmico, do antes e do depois, em que um instante está fora do outro. A idéia de que a eternidade é monótona provém da projeção do tempo da alma sobre o tempo do mundo. Esta projeção é inevitável (cf. acima: a aporética do tempo). Mas fazemos experiências que sugerem a idéia-limite duma constante surpresa sem sucessão de instantes. P. ex., um filme interessante que, segundo o relógio, dura duas horas, parece psicologicamente durar meia hora.

A idéia aristotélica do ato puro é desenvolvida por Tomás de Aquino, na sua última fase. $O$ ser é ato. Não só agere sequitur esse (agir segue ao ser). Quanto à eternidade devo formar a idéia-limite dum agir, ativo, com novidade, mas sem sucessão de instantes. Isto não é pensável objetivamente, categorialmente. Que a eternidade seja um contínuo jorrar de novidade, mas sem mudança, é um mistério a que posso aludir com a minha experiência de recolhimento (de que ainda vou falar) e expressar com metáforas. Usando as ironias de Thomas Mann: sempre ficamos entre a monotonia da "sopa de eternidade" (Ewigkeitssuppe) e a exaltação da Walpurgisnacht.

A partir das reflexões filosóficas sobre a História, podemos fazer outras alusões à eternidade. Assim como o homem é um ser-no-mundo-face-ao-mundo, também é um ser-na-História-face-à-História. É um cidadão de dois mundos - da transitoriedade e da perenidade. Situado num determinado período da História, pode distanciar-se dele e pensar sobre a História inteira. Pode dizer, p. ex., que a espécie humana já existe há mais de dois milhões de anos e, então, pode perguntar pela unidade da História.

Do ponto de vista fenomenológico, a consciência pode atravessar niveis de temporalização cada vez menos "distendidos" e mais tensos e mais densos revivendo o passado e antecipando o futuro, já anunciado no passado e no presente. É o 
recolhimento, de que são capazes os espíritos profundos. É o êxtase, inventado por alguns romancistas como variação imaginativa do tempo sucessivo do cotidiano e vivido pelos místicos - como experiência real ou como ilusão patológica.

Fazemos às vezes a experiência do "eterno presente" (Hegel), da unidade dos três ek-stases (Heidegger). Tais experiências de recolhimento sugerem a idéia duma eternidade, em que não há nem mudança, nem monotonia. Ricoeur expressa esta experiência com o conceito dialético de identidade narrativa: através das novidades e surpresas narráveis continuar a ser o mesmo.

Do ponto de vista duma especulação sobre a História, a eternidade é um apriori, algo que sempre pressupomos e que sempre buscamos. Poderíamos realmente pensar o tempo, se não tivéssemos a eternidade como pano de fundo? $\mathrm{E}$ suportariamos a transitoriedade, se nela não sentíssemos algo de eternidade, de "profunda eternidade" (Nietzsche)?

Do ponto de vista prático, paradoxalmente, a idéia de eternidade leva à iniciativa. A verdadeira iniciativa, tomada à luz da eternidade, retoma as potencialidades adormecidas da tradição, "torna presente" o possivel e necessário agora, como primeiro passo na direção do horizonte de expectativa, que se pode resumir com os termos: liberdade, comunicação sem coação e sem limite e união com Deus "face a face". Quem age sub specie aeternitatis tem tempo e não é desgastado pelo tempo. Ter tempo é... amar. A fé está ligada ao passado, a esperança ao futuro, o amor ao presente. "Agora estas três coisas permanecem: a Fé, a Esperança e a Caridade. Mas a maior delas é a Caridade" (1 Cor 13,13). 